\title{
PENGARUH MOBILISASI DINI TERHADAP PENYEMBUHAN LUKA POST OPERASI SECTIO CAESAREA
}

\author{
Theresia Eriyani ${ }^{1{ }^{*}}$, Iwan Shalahuddin ${ }^{2}$, Indra Maulana ${ }^{3}$ \\ ${ }^{1}$ Fakultas Keperawatan Unpad Kampus Garut; theresiaeriyani@gmail.com. \\ ${ }^{2}$ Fakultas Keperawatan Unpad Kampus Garut; shalahuddin.iwan@gmail.com. \\ ${ }^{3}$ Fakultas Keperawatan Unpad Kampus Garut; kang.indr476@yahoo.com. \\ *email: theresiaeriyani@gmail.com
}

\begin{abstract}
ABSTRAK
Word Health Organization menyatakan bahwastandar rata-rata sectiocaesarea disebuah negara adalah sekitar 5-15 \%. Berdasarkan Riset Kesehatan dasar tahun 2013, menyatakan persalinan sectiocaesarea di Indonesia sebesar 9,8\%. Selama proses penyembuhan luka, vaskularisasi akan mempengaruhi luka karena luka membutuhkan keadaan peredaran darah yang baik untuk pertumbuhan atau perbaikan sel. Mobilisasi akan memperlancar sirkulasi darah dan segera mungkin mengalami pemulihan atau penyembuhan. Tujuan dari penelitian ini adalah untuk mengetahui pengaruh mobilisasi dini terhadap penyembuhan luka pada pasien postoperasi sectiocaesarea di ruang Jade RSUD dr. Slamet Garut. Metode penelitian yang digunakan dalam penelitian ini adalah Quasi Experimental dengan pendekatan Posttest Only with Control Group, dengan populasi 80 ibu postoperasi sectiocaesarea, sampel penelitian berjumlah 20 ibu. Teknik pengumpulan data dengan observasi dan kuesioner. Analisa yang digunakan univariat dan bivariat menggunakan Shapiro-Wilk untuk normalitas dan NonParametrik dengan uji Mann-Whitney untuk bivariat. Hasil penelitian menunjukan adanya perbedaan penyembuhan luka yang signifikan dengan $p$-value sebesar $0,028(p<0,05)$ pada kelompok intervensi dan kelompok kontrol. Berdasarkan hasil penelitian ini diharapkan dapat menjadi rujukan tambahan dalam pemberian tindakan yang dapat meningkatkan penyembuhan luka, seperti penerapan Standar Operasional Prosedur mobilisasi dini pada pasien post operasi sectiocaesarea.
\end{abstract}

\section{Kata Kunci : Mobilisasi Dini, Penyembuhan Luka, Post Operasi, Sectio Caesarea}

\begin{abstract}
The Word Health Organization states that the average standard sectio caesarean in a country is around $5-15 \%$. Based on the basic Health Research in 2013, it was stated that sectiocaesarea delivery in Indonesia was $9.8 \%$. During the wound healing process, vascularization will affect the wound because the wound requires a circulatory state that is good for cell growth or repair. Mobilization will facilitate blood circulation and may soon experience recovery or healing. The purpose of this study was to determine the effect of early mobilization on wound healing in patients with postoperative caesarean section in the Jade room of RSUD dr. SlametGarut. The research method used in this study was Quasi Experimental with the approach of Posttest Only with Control Group, with a population of 80 mothers postoperative caesarean section, the study sample amounted to 20 mothers. The technique of collecting data is by observation and questionnaire. Univariate and bivariate analysis used Shapiro-Wilk for normality and NonParametric with Mann-Whitney test for bivariate. The results showed a significant difference in wound healing with a $p$-value of $0.028(p<0.05)$ in the intervention group and the control group. Based on the results of this study, it is expected to be an additional reference in the provision of actions that can improve wound healing, such as the application of Operational Standards Procedures for early mobilization in patients postoperative caesarean section.
\end{abstract}


Keywords : Early Mobilization, Wound Healing, Post Surgery, Sectio Caesar 


\section{PENDAHULUAN}

Persalinan dan kelahiran merupakan kejadian fisiologis, pada proses persalinan terjadi pengeluaran bayi, plasenta, dan membrane dari dalam Rahim melalui jalan lahir. Proses ini berawal dari pembukaan dan dilatasi serviks sebagai akibat kontraksi uterus dengan frekuensi, durasi, dan kekuatan yang teratur. Persalinan dianggap normal jika prosesnya terjadi pada usia kehamilan cukup bulan (setelah 37 minggu) tanpa disertai adanya penyulit (Yuliastanti, T., \&Nurhidayati, N. (2013).

Wanita yang akan menghadapi persalinan pasti menginginkan persalinannya berjalan lancar dan dapat melahirkan bayi yang sempurna. Namun, tidak jarang proses persalinan mengalami hambatan dan harus dilakukan dengan tindakan pembedahan (sectiocaesarea), baik karena pertimbangan untuk menyelamatkan ibu dan janinnya ataupun keinginan pribadi pasien. Sectiocaesarea merupakan suatu tindakan untuk melahirkan bayi melalui sayatan pada dinding uterus yang masih utuh (Winkjosastro, 2008).

Word Health Organization (WHO) menyatakan bahwa standar rata-rata Sectio Caesarea di sebuah negara adalah sekitar $5-15 \%$. Di rumah sakit pemerintah rata-rata $11 \%$ sementara di rumah sakit swasta bisa lebih dari $30 \%$. Angka Sectio Caesarea terus meningkat 3-4 \% 15 tahun yang lampau, sampai insidensi 10 hingga $15 \%$ sekarang ini (Oxorn, DC 2011). Berdasarkan data RISKESDAS tahun 2013, tingkat persalinan sectio caesarea di Indonesia sebesar 9,8\% dengan proporsi tertinggi di DKI Jakarta (19,9 \%). Di Jawa Barat persalinan melalui operasi sectio caesarea berkisar antara 7\%-9\% dari total persalinan (Dinas Kesehatan Provinsi Jawa Barat, 2012). Data yang diperoleh selama tahun 2013 di RSUD dr. Slamet Garut jumlah ibu yang melahirkan melalui pembedahan sectio caesarea sebanyak 617 orang (6,5\%) dan lebih dari $60 \%$ penyembuhan luka post operasinya cukup lama dan sulit (Medical Record, RSUD dr. Slamet Garut).
Setelah ibu mengalami persalinan baik secara normal atau melalui tindakan pembedahan sectiocaesarea akan ada masa pemulihan yang disebut dengan masa nifas. Pada masa nifas ibu banyak mengalami kejadian yang penting. Mulai dari perubahan fisik, masa laktasi maupun perubahan psikologis menghadapi keluarga baru dengan kehadiran buah hati yang sangat membutuhkan perhatian dan kasih saying (Safrudin SK, , 2009).

Pada ibu yang bersalin secara sectio caesarea lebih beresiko mengalami komplikasi daripada ibu yang bersalin secara normal. Komplikasi yang dapat terjadi diantaranya infeksi puerperal (nifas), pendarahan yang disebabkan oleh banyaknya pembuluh darah yang terputus dan terbuka, emboli pulmonal, luka pada kandung kemih serta kemungkinan rupture uteri spontan pada kehamilan mendatang (Ulfah M, 2013). Selain itu tindakan pembedahan sectiocaesarea yang dilakukanakan meninggalkan sebuah kondisi luka insisi. Akibat dari insisi ini akan menimbulkan terputusnya jaringan tubuh dan menjadikan luka pada orang yang dilakukan pembedahan.

Perry dan Potter (2005) menjelaskan bahwa luka merupakan rusaknya struktur dan fungsi anatomis normal akibat proses patologis yang berasal dari internal maupun eksternal dan mengenai organ tertentu. Penyembuhan luka dipengaruhi oleh beberapa faktor yakni, nutrisi, umur, vaskularisasi, anemia, status imunologi, kadar gula darah dan obesitas. Johnson (2005), menjelaskan bahwa penyembuhan luka dimulai sejak terjadinya cidera pada tubuh dan terdapat 4 fase penyembuhan luka yaitu hemostatis, inflamasi, proliferasi, maturasi.

Dalam mengatasi luka insisi akibat dari operasi sectio caesarea maka diperlukan tindakan dan bimbingan dari petugas kesehatan untuk mempercepat proses penyembuhan luka diantaranya memenuhi kebutuhan nutrisi yang bergizi seimbang dan cairan yang cukup, dengan melakukan mobilisasi dini, istirahat yang cukup sekitar 8 jam pada malam hari dan 1 jam pada siang hari, melakukan senam 
nifas dan penanganan insisi (Heryani, 2012).

Proses penyembuhan luka pada tubuh yang sehat mempunyai kemampuan untuk melindungi dan memulihkan dirinya, peningkatan aliran darah ke daerah yang rusak, membersihkan sel dan benda asing dan perkembangan awal seluler bagian dari proses penyembuhan (Sukisno, AT, 2015). Menurut Perry \& Potter (2005) menyatakan bahwa vaskularisasi mempengaruhi luka karena luka membutuhkan keadaan peredaran darah yang baik untuk pertumbuhan atau perbaikan sel. Mobilisasi akan memperlancar sirkulasi darah dan segera mungkin mengalami pemulihan atau penyembuhan (Mariati, M, 2015).

$$
\text { Pada prinsipnya proses }
$$
penyembuhan luka pada semua luka sama, dengan variasinya bergantung pada lokasi, keparahan dan luasnya cedera. Kemampuan sel dan jariangan melakukan regenerasi atau kembali ke struktur normal melalui pertumbuhan sel juga mempengaruhi penyembuhan luka (Perry \& Potter, 2005). Salah satu konsep dasar perawatan pada masa nifas pasien pasca sectio caesarea didapatkan bahwa mobilisasi dini diberikan setelah sectio caesarea (Manuaba, 2010). Selain itu, berdasarkan hasil penelitian yang telah dilakukan oleh Puspitasari HA, Sumarsih T, (2011) menunjukan bahwa faktor yang mempengaruhi proses penyembuhan luka pada pasien post operasi sectio caesarea $75 \%$ dipengaruhi oleh mobilisasi, $75 \%$ personal hygiene dan $47 \%$ dipengaruhi oleh nutrisi. Dengan demikian adanya mobilisasi secara langsung berdampak pada akselerasi proses penyembuhan post partum.

Mobilisasi dini merupakan suatu upaya mempertahankan kemandirian sedini mungkin dengan cara membimbing penderita untuk mempertahankan fungsi fisiologi. Mobilisasi pasca sectiocaesarea adalah suatu pergerakan, posisi atau adanya kegiatan yang dilakukan ibu setelah beberapa jam melahirkan dengan Sectio Caesarea (Sudiharjani, 2012). Hampir semua jenis operasi membutuhkan mobilisasi atau pergerakan badan sedini mungkin. Mobilisasi sudah dapat dilakukan sejak 8 jam setelah pembedahan, dan setelah pasien sadar atau anggota gerak tubuh dapat digerakkan kembali setelah dilakukan pembiusan regional (Rasjidi I, 2009).

Data yang diperoleh dari Rumah Sakit Umum Daerah dr. Slamet Garut selama bulan Januari 2017 menunjukan bahwa ibu yang mengalami persalinan dengan tindakan sectiocaesarea yakni sebanyak 80 orang. Berdasarkan data tersebut peneliti melakukan studi pendahuluan yang dilakukan di ruang Jade RSUD dr. Slamet Garut peneliti melakukan observasi kepada 10 orang pasien post operasi sectiocaesarea hari pertama. Dari hasil observasi menunjukan bahwa 7 diantaranya tidak melakukan mobilisasi dini seperti berbaring miring kiri miring kanan, latihan pernafasan, duduk, berjalan.

Hari ketiga dari 10 pasien tersebut 4 diantaranya keadaan luka pada pasien tersebut masih terjadi sedikit perdarahan dan adanya tanda infeksi pada luka seperti suhu badan yang meningkat, kemerahan pada luka, pembengkakan serta nyeri pada luka operasi sectio caesarea.

Upaya yang selama ini dilakukan oleh perawat ruangan tersebut yakni menganjurkan untuk melakukan mobilisasi secara perlahan sesuai dengan Standar Operasional Prosedur dengan dibantu oleh keluarganya dan melakukan perawatan luka pada pasien post operasi sectiocaesarea tersebut. Berdasarkan fenomena diatas peneliti tertarik untuk meneliti pengaruh mobilisasi dini terhadap penyembuhan luka pada pasien post operasi sectiocaesarea di ruang Jade RSUD dr. Slamet Garut.

\section{METODE PENELITIAN}

Desain penelitian yang digunakan dalam penelitian ini adalah Quasi Experimental dengan pendekatan Posttest Only with Control Group. Dengan rancangan ini, memungkinkan peneliti mengukur pengaruh perlakuan (intervensi) pada kelompok eksperimen dengan cara membandingkan kelompok tersebut 
dengan kelompok kontrol (Notoatmodjo, 2010).

Populasi penelitian ini sebanyak 80 orang ibu post operasi sectiocaesarea yang dilakukan perawatan di ruang Jade RSUD dr. Slamet Garut. Sampel pada penelitian ini berjumlah 20 orang dengan rentang usia dari 21-35 tahun, dengan pembagian 10 orang kelompok intervensi dan 10 orang kelompok control dengan Indikasi dilakukannya operasi sectiocaesarea pada responden adalah karena panggul sempit serta mal persentasi janin seperti letak lintang dan letak sungsang.

Penelitian dilakukan selama 3 hari, dari hari pertama hingga hari ketiga pasien kelompok intervensi mendapatkan perlakukan berupa mobilisasi dini, sedangkan pada kelompok control pasien tidak diberikan perlakuan mobilisasi dini. Pada hari ketiga pasien kelompok kontrol dan kelompok intervensi dilakukan penilaian dari penyembuhan luka pasien postoperasis ectiocaesarea dengan menggunakan skala REEDA (Redness, Edema, Ecchymosis, Discharge, Approximation) merupakan instrument penilaian penyembuhan luka yang berisi lima faktor, yaitu kemerahan, edema, ekimosis, discharge, dan pendekatan (aproksimasi) dari dua tepi luka. Masingmasing factor diberi skor antara 0 sampai 3 yang merepresentasikan tidak adanya tanda-tanda hingga adanya tanda-tanda tingkat tertinggi. Dengan demikian, total skor skala berkisar dari 0 sampai 15 , dengan skor yang lebih tinggi menunjukkan penyembuhan luka yang jelek. Pengamatan dilakukan 2 kali yaitu pada hari ke-2 setelah sectiocaesarea.

Analisa Data dilakukan dengan univariat dan bivariat menggunakan Shapiro-Wilk untuk normalitas dan NonParametrik dengan uji Mann-Whitney untuk bivariate.

Gambaran tentang desain penelitian yang akan dilakukan digambarkan dalam began berikut:

\section{Bagan. 1. Desain Penelitian Quasi Eksperimental Pendekatan Posttest Only with Control Group Design}

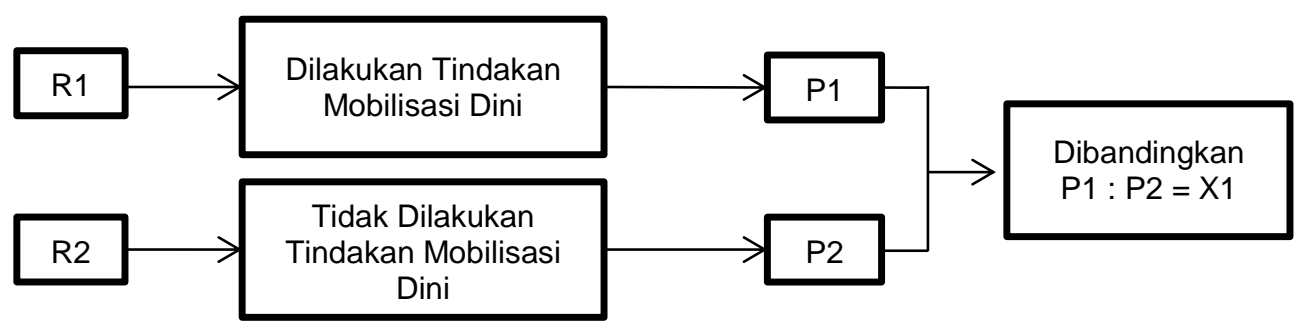

\section{HASIL PENELITIAN}

Tabel1. Distribusi Penyembuhan Luka pada Kelompok Intervensi

\begin{tabular}{ccc}
\hline \multirow{2}{*}{ Skala REEDA } & \multicolumn{2}{c}{ Kelompok Intervensi } \\
\cline { 2 - 3 } & Frekuensi & Persentasi \\
\hline Kurang Baik & 2 & 20 \\
\hline Baik & 8 & 80 \\
\hline Jumlah & 10 & 100 \\
\hline Sumber: Analisis Univariat & &
\end{tabular}

Berdasarkan tabel1, dapat diketahui bahwa penyembuhan luka pada kelompok intervensi yakni kelompok yang diberikan
Perlakuan berupa mobilisasi dini, hamper seluruh dari responden mengalami penyembuhan luka yang baik dengan jumlah responden 8 responden (80\%). 
Tabel 2. Distribusi Penyembuhan Luka pada Kelompok Kontrol

\begin{tabular}{|c|c|}
\hline \multirow{2}{*}{ Skala REEDA } & Kelompok Kontrol \\
\hline & $\begin{array}{ll}\text { Frekuensi } & \text { Persentasi }\end{array}$ \\
\hline Kurang Baik & 60 \\
\hline Baik & 40 \\
\hline Jumlah & 100 \\
\hline $\begin{array}{l}\text { Sumber: Analisis Univariat } \\
\text { Berdasarkan Tabel diatas dapat } \\
\text { gambarkan bahwa persentase } \\
\text { enyembuhan luka pada kelompok control } \\
\text { ebagian besar dari responden mengalami } \\
\text { enyembuhan luka yang kurang baik } \\
\text { engan jumlah } 6 \text { responden. } \\
\text { Analisis bivariat dilakukan untuk } \\
\text { enguji hipotesis penelitian, yaitu untuk } \\
\text { enentukan ada atau tidaknya pengaruh } \\
\text { obilisasi dini terhadap penyembuhan } \\
\text { ka pada pasien postoperasi } \\
\text { ectiocaesarea di ruang Jade RSUD dr. }\end{array}$ & $\begin{array}{l}\text { menggunakan Analisa bivariat data ini } \\
\text { diujinormalitasnya. Uji normalitas data ini } \\
\text { menggunakan uji Shapiro-Wilk karena data } \\
\text { kurang dari } 50(\mathrm{n}=20) \text {. Berdasarkan hasil } \\
\text { uji Shapiro-Wilk diperoleh nilai signifikan } \\
\text { untuk penyembuhan luka kelompok kontrol } \\
\text { dan kelompok intervensi sebesar } 0.000 \text {. } \\
\text { Pada uji normalitas ini data dikatakan tidak } \\
\text { berdistribusi normal dikarenakan nilai } \\
\text { p<0,05. Karena data berdistribusi tidak } \\
\text { normal maka menggunakan Analisa } \\
\text { bivariat Non-Parametrik dengan uji Mann- } \\
\text { Whitney }\end{array}$ \\
\hline
\end{tabular}

Slamet Garut. Sebelum menganalisa

Tabel3. Perbedaan Penyembuhan Luka pada Kelompok Intervensi dan Kelompok Kontrol di Ruang Jade RSUD dr. Slamet Garut

\begin{tabular}{ccccc}
\hline & $\mathrm{n}$ & $\begin{array}{c}\text { Penyembuhan Luka } \\
\text { KurangBaik }\end{array}$ & $\begin{array}{c}\text { Penyembuhan } \\
\text { Luka Baik }\end{array}$ & P Value \\
\hline Kelompok Intervensi & 10 & 2 & 8 & \multirow{2}{*}{0,028} \\
\hline Kelompok Kontrol & 10 & 6 & 4 & \\
\hline Sumber: Analisis Bivariat & & & &
\end{tabular}


Analisa statistik dengan uji Mann Whitney menunjukan nilai sig atau $p$ value sebesar 0,028 yang berarti nilai $p<0,05$. Apabila nilai $p$ value<batas kritis 0,05 maka terdapat perbedaan bermakna antara dua kelompok atau yang berarti hipotesis nol ditolak, yaitu ada pengaruh mobilisasi dini terhadap penyembuhan luka pada pasien postoperasi sectiocaesarea

\section{PEMBAHASAN}

Penyembuhan luka pada pasien post operasi sectiocaesarea sesudah dilakukan mobilisasi dini pada kelompok intervensi hamper seluruh dari responden mengalami penyembuhan luka yang baik dengan jumlah 8 responden. Berdasarkan teori, penyembuhan luka adalah suatu proses yang kompleks dan umumnya terjadi secara teratur yang melibatkan regenerasi epitel dan pembentukan parut jaringan ikat. Penyembuhan luka akan melibatkan proses fisiologis. Sifat penyembuhan dari semua luka sama, hanya ada beberapa hal yang membedakan yaitu bergantung pada lokasi, tingkat keparahan, dan luasnya luka. Namun yang paling menentukan adalah kemampuan sel untuk beregenerasi (kembali ke struktur normal) (Potter, R, at al, 2006).

Luka setelah dilakukan pembedahan sectiocaesarea akan mengalami proses penyembuhan luka yang terdiri dari 3 fase, yaitu fase inflamasi, fase proliferasi dan fase maturasi (Potter, R, at al, 2006). Fase inflamasi dimulai dari adanya reaksi tubuh terhadap luka dimulai dari beberapa menit setelah cedera dan berlangsung selama beberapa hari. Dalam fase ini terjadi proses hemostatis (pengontrolan perdarahan) yaitu sesuai dengan perintah otak, tubuh akan mengirim suplai darah ke area yang mengalami cedera, kemudian membentuk sel-sel epitel (epitelisasi) (Potter, R, at al, 2006). Selama proses ini pembuluh darah yang menyuplai darah ke area luka akan mengalami kontriksi dan trombosit akan berkumpul di area luka untuk menghentikan proses perdarahan dengan membentuk jaring-jaring benang fibrin (matriks fibrin) dari matrik fibrin inilah yang nantinya akan menjadi kerangka perbaikan sel. Kemudian jaringan yang rusak menyekresikan histamin yang merangsang vasodilatasi kapiler di area luka dan mengeluarkan serum dan sel darah putih (Potter, R, at al, 2006).

Penelitian ini dilakukan pada pasien hari ketiga setelah dilakukan operasi sectiocaesarea, berdasarkan teori proses penyembuhan luka ini terdapat pada fase inflamasi, pada fase ini akan terjadi proses homeostatis dan akan mengalami proses epitalisasi, sehingga pada luka yang baik akan terbentuk sel-sel epitel sehingga luka akan tertutup dan mengeluarkan serum dan sel darah putih. Hal tersebut sejalan dengan hasil penelitian yang terdapat dalam tabel 1 dengan menunjukan hamper seluruh dari responden mengalami penyembuhan luka yang baik karena pada saat dilakukan observasi menunjukan keadaan luka yang sudah tertutup meskipun terdapat 5 responden dengan tanda kemerahan di sekitar 0,25 luka insisi, namun luka dalam keadaan kering (tidak terdapat pengeluaran cairan) dan tidak terdapat tanda-tanda edema atau ecchymosis.

Penyembuhan luka pada pasien post operasi sectiocaesarea yang tidak dilakukan mobilisasi dini pada kelompok kontrol sebagian besar dari responden mengalami penyembuhan luka yang kurang baik dengan jumlah 6 responden. Berdasarkan teori proses penyembuhan luka pada fase inflamasi akan terjadi proses homeostatis dan akan mengalami proses epitalisasi, sehingga pada luka yang baik akan terbentuk sel-sel epitel sehingga luka akan tertutup dan mengeluarkan serum dan sel darah putih. Namun keadaan ini tidak sejalan dengan hasil dari penelitian yang dilakukan pada kelompok kontrol yang sebagian besar dari responden mengalami penyembuhan luka yang kurang baik, hal ini ditunjukan dengan 2 responden yang terdapat pemisahan kulit, 4 responden yang terdapat tanda kemerahan di sekitar luka insisi, 2 responden yang terdapat pengeluaran serum atau serosanguinous dan masih terdapat tanda-tanda baik edema ataupun ecchymosis.

Pengaruh mobilisasi dini terhadap penyembuhan luka pada pasien post operasi sectiocaesarea berdasarkan hasil penelitian pada tabel 3 menunjukan bahwa pada kelompok intervensi hamper seluruh dari responden mengalami penyembuhan luka 
yang baik dengan jumlah 8 responden. Sedangkan pada kelompok control sebagian besar dari responden mengalami penyembuhan luka yang kurang baik dengan jumlah 6 responden. Analisa statistik dengan uji Mann Whitney menunjukan nilai sig atau $p$ value sebesar 0,028 yang berarti nilai $p<0,05$. Apabila nilai $p$ value < batas kritis 0,05 maka terdapat perbedaan bermakna antara dua kelompok atau yang berarti hipotesis nol ditolak, yaitu ada pengaruh mobilisasi dini terhadap penyembuhan luka pada pasien postoperasi sectiocaesarea.

Berdasarkan teori menurut Perry \& Potter (2005) menyatakan bahwa vaskularisasi mempengaruhi luka karena luka membutuhkan keadaan peredarandarah yang baik untuk pertumbuhan atau perbaikan sel. Mobilisasi akan memperlancar sirkulasi darah dan segera mungkin mengalami pemulihan atau penyembuhan (Susilowati D. 2015).

Mobilisasi dini merupakan suatu upaya mempertahankan kemandirian sedini mungkin dengan cara membimbing penderita untuk mempertahankan fungsi fisiologi. Mobilisasi post sectiocaesarea adalah suatu pergerakan posisi atau adanya kegiatan yang dilakukan ibu setelah beberapa jam melahirkan dengan persalinan caesarea (Winarta, 2010). Hampir semua jenis operasi membutuhkan mobilisasi atau pergerakan badan sedini mungkin (Rasjidi I, 2009).

Mobilisasi pada post sectiocaesarea salah satunya adalah perubahan gerak dan posisi. Ini dan harus diterangkan kepada penderita dan keluarga yang menunggu, agar mengerti pentingnya mobilisasi dini berkesinambungan akan dapat membantu pengaliran darah keseluruh tubuh, sehingga tubuh mampu menghasilkan zat pembakar dan pembangun yang membantu proses penyembuhan luka. Mobilisasi dini dapat dilakukan pada kondisi pasien yang membaik. Pada pasien postoperasi sectiocaesarea 6 jam pertama dianjurkan untuk segera menggerakkan anggota tubuhnya. Gerak tubuh yang bias dilakukan adalah menggerakkan tangan, lengan, kaki dan jarijarinya agar kerja organ pencernaan segera kembali normal (Kasdu, 2005).

Hasil dari penelitian tersebut sejalan dengan teori yang dinyatakan oleh Perry \& Potter (2005) yang menyatakan bahwa vaskularisasi akan berpengaruh terhadap penyembuhan luka dan mobilisasi yang dilakukan akan memperlancar peredaran darah dan dapat mempercepat terhadap pemulihan dan penyembuhan luka. Sehingga dari hasil penelitian ini dapat terlihat bahwa pada kelompok yang tidak mendapatkan intervensi berupa mobilisasi dini menunjukan sebagian besar dari responden yang mengalami penyembuhan luka yang kurang baik dapat ditunjukan dengan 2 responden yang masih terdapat pemisahan kulit, 4 responden yang masih terdapat tanda kemerahan disekitar luka insisi, 2 responden yang terdapat pengeluaran serum atau serosanguinous dan masih terdapat tandatanda baik edema ataupun ecchymosis, hal ini dikarenakan vaskularisasi ke daerah luka kurang maksimal dengan tidak adanya mobilisasi yang dilakukan oleh ibu post operasi sectiocaesarea sehingga proses dari penyembuhan luka menjadi kurang baik.

Pada kelompok intervensi yang diberikan perlakuan berupa mobilisasi dini akan memaksimalkan peredaran darah dan vaskularisasi yang baik ke daerah luka sehingga proses penyembuhan luka dapat berjalan dengan maksimal, hal ini dapat dibuktikan dengan hasil penelitian yang menunjukan hamper seluruhnya dari responden mengalami penyembuhan luka yang baik, pada saat dilakukan observasi menunjukan keadaan luka yang sudah tertutup meskipun terdapat 5 responden dengan tanda kemerahan disekitar 0,25 luka insisi, namun luka dalam keadaan kering (tidak terdapat pengeluaran cairan) dan tidak terdapat tanda-tanda edema atau ecchymosis. Sehingga dapat terlihat perbedaan kondisi Luka setelah diberikan mobilisasi dini.

Penelitian ini sejalan dengan penelitian hasil penelitian yang telah dilakukan oleh Susilowati, D (2015) menunjukan bahwa faktor yang mempengaruhi proses penyembuhan luka pada pasien post operasi sectiocaesarea $75 \%$ dipengaruhi oleh mobilisasi, $75 \%$ personal hygiene dan $47 \%$ dipengaruhi oleh nutrisi. Dengan demikian adanya mobilisasi secara langsung berdampak pada akselerasi proses penyembuhan post partum. 
Hasil penelitian ini dapat memberikan gambaran bahwa penyembuhan luka akan lebih maksimal apabila pasien yang mengalami postoperasi sectiocaesarea diberikan intervensi berupa mobilisasi dini.

\section{SIMPULAN DAN SARAN \\ 1. Simpulan}

Dari hasil penelitian yang telah dilakukan, dapat disimpulkan bahwa ada pengaruh yang signifikan dalam penyembuhan luka pada pasien post operasi sectiocaesarea yang dilakukan mobilisasi dini. Hal tersebut dapat dijelaskan seperti berikut: Penyembuhan luka pada kelompok kontrol, sebagian besar dari responden mengalami penyembuhan luka yang kurang baik; Penyembuhan luka pada kelompok intervensi, hamper seluruh dari responden mengalami penyembuhan luka yang baik; Terdapat pengaruh mobilisasi dini terhadap penyembuhan luka pada pasien post operasi sectiocaesarea di ruang Jade RSUD dr. Slamet Garut Tahun 2017 dengan nilai $p$ value 0,028

\section{Saran}

Berdasarkan hasil penelitian, saran yang dapat diajukan antara lain:

1. Bagi Instansi Rumah Sakit: Hasil dari penelitian ini dapat dijadikan rujukan tambahan bagi pelayanan kesehatan di Rumah Sakit, khususnya dalam pemberian tindakan yang dapat meningkatkan penyembuhan luka pada pasien yang telah menjalankan operasi sectiocaesarea, seperti penerapan SOP mobilisasi dini pada pasien post operasi sectiocaesarea dan dapat menjadi referensi tentang penyembuhan luka khususnya pada pasien post operasi sectiocaesarea dalam memberikan asuhan keperawatan.

2. Bagi Peneliti Lainnya: diharapkan hasil penelitian ini dapat digunakan sebagai data awal untuk meneliti tentang penyembuhan luka yang lebih lanjut. Peneliti selanjutnya dapat meneliti tentang efektivitas tindakan lain yang dapat mempengaruhi penyembuhan luka. Selain itu, peneliti yang lain dapat melakukan penelitian pada faktor-faktor lainnya yang mempengaruhi terhadap penyembuhan luka.

\section{DAFTAR PUSTAKA}

Deni K. Operasi caesarea masalah dan solusinya. 2005

Heryani R. Asuhan Kebidanan Ibu Nifas dan Menyusui. Jakarta: TIM. 2012.

Johnson R, Taylor W. Buku Ajar: Praktik Kebidanan; (Skills for Midwifery Practice). EGC. 2005

Manuaba IB. Kapita selekta penatalaksanaan rutin obstetri, ginekologi, dan KB. Egc. 2010

Mariati M. Pengaruh Pemberian Pendidikan Kesehatan Mobilisasi Dini Dengan Lama Hari Rawat Pada Pasien Post Operasi SectioCaesaria. Jurnal Media Kesehatan. 2015;8(2):106-12.

Notoatmodjo S. Metodologi penelitian kesehatan. 2010

Oxorn DC. Intraoperative echocardiography. Elsevier Health Sciences; 2011.

Potter PA, Perry AG. Buku ajar fundamental keperawatan: konsep, proses, dan praktik. Jakarta: Egc. 2005;1.

Pötter R, Haie-Meder C, Van Limbergen E, Barillot I, De Brabandere M, Dimopoulos J, Dumas I, Erickson B, Lang S, Nulens A, Petrow P. Recommendations from gynaecological (GYN) GEC ESTRO working group (II): Concepts and terms in 3D image-based treatment planning in cervix cancer brachytherapy-3D dose volume parameters and aspects of $3 D$ image-based anatomy, radiation physics, radiobiology. Radiotherapy and Oncology. 2006 Jan 1;78(1):67-77.

Puspitasari HA, Sumarsih T. Faktor-faktor yang mempengaruhi Penyembuhan Luka Post Operasi Sectio Caesarea (SC). Jurnal Ilmiah Kesehatan Keperawatan. 2011 Feb 1;7(1). 
Rasjidi I. Manual Seksio Sesarea \& Laparotomi Kelainan Adneksa. CV Sagung Seto. Jakarta. 2009.

Safrudin SK, Kes M, Hamidah SP, Kes M. Kebidanan komunitas. EGC. 2009

Sudiharjani N. Mobilisasi Dini Dan Penyembuhan Luka Operasi Pada lbu Post Sectio Caesarea (Sc) Di Ruang Dahlia Rumah Sakit Umum Daerah Kota Salatiga. Inprosiding Seminar Nasional \& Internasional 2012.

Sukisno At. Lama Penyembuhan Luka Perineum Pada lbu Post Partum Yang Melakukan Senam Nifas Di Polindes Ngembeh Dlanggu Kabupaten Mojokerto. Kti D3 Kebidanan. 2015 May 15.

Susilowati D. Faktor-Faktor Yang Mempengaruhi Ibu Nifas Dalam Pelaksanaan Mobilisasi Dini. Jurnal INFOKES Universitas Duta Bangsa Surakarta. 2015 Dec 2;5(2).

Ulfah M. Perbedaan Kadar Hemoglobin Pada Pasien SeksioSesarea Pertama Dengan Pasien SeksioSesarea Berulang Di Rs. PrikasihTahun 2013.

Winkjosastro H. Hanada. Perdarahan Pasca Persalinan. Disitasi tanggal. 2008 Sep;21.

Yuliastanti T, Nurhidayati N. Pendampingan Suami Dan Skala Nyeri Pada Persalinan Kala 1 Fase Aktif. Bidan Prada: Jurnal Publikasi Kebidanan Akbid YLPP Purwokerto. 2013 Dec 6;4(01). 